\title{
Secondary School Teachers' Concerns about ICT Integration: Perspectives from a Developing Part of the Globe
}

\author{
Nazir Ahmed Jogezai ${ }^{1 *}$, Shaik Abdul Malik Mohamed Ismail ${ }^{1}$, Fozia Ahmed Baloch ${ }^{1}$ \\ ${ }^{1}$ School of Educatioanal Studies, Universiti Sains Malaysia, Penang, MALAYSIA
}

Received 1 April 2018 • Revised 4 June 2018 • Accepted 15 July 2018

\begin{abstract}
Teachers' eagerness and concern, has been at the heart of the successful implementation of an educational innovation. This study aimed at exploring teachers' concern regarding ICT integration with employing explanatory mixed method research design. The sample size of 300 Pakistani secondary school teachers was identified for the quantitative and 35 for the qualitative part of the study. Stages of concern questionnaire (SoCQ), was adopted as data collection instrument for the quantitative and semi structured interviews for the qualitative part of the study. The findings portray a non user profile of the teachers because of their high concerns, high mean scores, at the stages of unconcerned $(M=75.85)$, informational $(M=59.99)$, and personal $(M=57.66)$. Consequently, low concerns, with very low mean scores, on consequence $(M=6.83)$, collaboration (12.00) and refocusing stages (12.79). The findings suggest for an ongoing and school based capacity enhancement to remain at the heart of reform agenda of ICT integration to meet and accommodate teachers' early stages of concern and enable them move gradually towards their impact related concern profile.
\end{abstract}

Keywords: secondary school, teacher, concern, ICT integration, teaching \& learning

\section{INTRODUCTION}

ICT integration, in the process of teaching and learning, earns a considerable recognition worldwide. A substantial research (e.g. Gakuo \& Kidombo, 2011; Harris \& Hofer, 2011; Mikre, 2011; Miranda \& Russell, 2012; Ouyang, 2017; Razzak, 2013; Rosenberg \& Koehler, 2015; Swan \& Hofer, 2011; Xu \& Chen 2016; Zhou, Xu, \& Martinovic, 2017) find ICT use in classroom setting very much crucial for meaningful teaching and learning processes.

Realizing the importance of ICT integration in the process of teaching and learning, likewise in the developed part of the world, research in many of the developing countries for example in Kuwait Alrwaished, Alkandari, and Alhashem (2017) Pakistan Jogezai, Ismail, and Ahmed (2016), Kenya (Kirskoi, 2015), South Africa (Niekerk \& Blignaut, 2014; Ramorola, 2013) and Tunzania (Mwalongo, 2011), also inform about their countries to have invested a lot into integrating ICT in the process of teaching and learning.

In Pakistan ICT integration receives phenomenal attention of the government, policy makers, educational authorities and researchers. The educational policies and plans for example national education policy (NEP 2009) underpin ICT integration as a viable initiative for improving overall quality of education in the country. In addition to that, Pakistan vision 2025 and national ICT strategy 2004 strongly emphasize on effective ICT integration in the process of teaching and learning. Similarly, since 2011 a number of research (e.g. Adil, Masood, \& Ahmed, 2013; Hassan, \& Sajid, 2012; ; Jogezai et al., 2016; Kanwal, Jan, \& Azhar, 2014; Majoka, Fazal, \& Khan 2013; Nisar, Munir, \& Shad, 2011; Qadir \& Hameed 2014; Shaikh \& Khoja, 2013) has been conducted in Pakistan in this regard.

Research, in the realm of ICT integration, highly focuses on teachers as key players in implementing ICT integration. Their attitude (Yücel, Acun, Tarman, \& Mete, 2010) pedagogical beliefs (Baser-Gulsoy, 2011) and training (Hismanoglu, 2012) are considered phenomenal towards ICT integration. Similarly, as Fullan (2007) argues that successful ICT integration depends on how teachers interpret or understand ICT integration and how much they are concerned about it. Research (e.g. Hao \& Lee, 2017) informs that teachers' concerns have highly influenced

(c) 2018 by the authors; licensee Modestum Ltd., UK. This article is an open access article distributed under the terms and conditions of the Creative Commons Attribution License (http://creativecommons.org/licenses/by/4.0/). $\square$ nazeer_khan53@yahoo.com (*Correspondence) $\square$ samohame@gmail.com $\square$ foziaahmed4@yahoo.com 


\section{Contribution of this paper to the literature}

- The study investigated secondary school teachers' concern about ICT use in teaching and learning. This was valuable in order to generate new knowledge from the perspective of secondary school teachers' concern about implementing an innovation. In particular, the study remains significant in the context of a developing country like Pakistan where ICT integration remains prominent amid government agenda of educational reforms.

- With the approach of employing a mixed method research the findings portray teachers' higher or peak concerns along with presenting the associated causes in this regard.

- The findings are of significance for the government, education department, and policy makers to consider teachers' concerns with relation to ICT integration in schools.

- The study, on the basis of its findings, suggests valuable areas for future research with relation to ICT integration.

Table 1. Description of stages of concern

\begin{tabular}{|c|c|c|c|}
\hline Patterns & Stages of Concern & Definition & Expression \\
\hline \multirow[t]{3}{*}{ Impact } & Refocusing & $\begin{array}{l}\text { The focus is on the exploration of more universal benefits from the } \\
\text { innovation, including the possibility of major changes or replacement } \\
\text { with a more powerful alternative. Individual has definite ideas about } \\
\text { alternatives to the proposed or existing form of the innovation. }\end{array}$ & $\begin{array}{l}\text { I have some ideas about } \\
\text { something that works } \\
\text { even better }\end{array}$ \\
\hline & Collaboration & $\begin{array}{l}\text { Focuses on coordination and } \\
\text { cooperation with others regarding the use of innovation }\end{array}$ & $\begin{array}{l}\text { I am concerned about } \\
\text { relating what I am doing } \\
\text { with what my co-workers } \\
\text { are doing }\end{array}$ \\
\hline & Consequences & $\begin{array}{l}\text { Focuses on the impact of the innovation in the immediate sphere of } \\
\text { influence }\end{array}$ & $\begin{array}{l}\text { How is my use affecting } \\
\text { my students }\end{array}$ \\
\hline Task & Management & $\begin{array}{l}\text { Attention is focused on the processes and tasks of using the } \\
\text { innovation and the best use of information and resources. Issues } \\
\text { related to efficiency, organizing, managing, scheduling, and time } \\
\text { demands are utmost. }\end{array}$ & $\begin{array}{l}\text { I seem to be spending all } \\
\text { of my time getting } \\
\text { materials ready }\end{array}$ \\
\hline \multirow[t]{2}{*}{ Self } & Personal & $\begin{array}{l}\text { Individual is uncertain about the demands of the innovation, his/her } \\
\text { inadequacy to meet those demands, and his/her role with the } \\
\text { innovation. This includes analysis of his/her role in relation to the } \\
\text { reward structure of the organization, decision making, and } \\
\text { consideration of potential conflicts with existing structures or } \\
\text { personal commitment. Financial or status implications of the program } \\
\text { for self and colleagues may also be reflected. }\end{array}$ & $\begin{array}{l}\text { How will using it affect } \\
\text { me? }\end{array}$ \\
\hline & Informational & $\begin{array}{l}\text { A general unconcerned of the innovation and interest in learning } \\
\text { more detail about it is indicated. The person seems to be unworried } \\
\text { about him/her in relation to the innovation. She/he is interested in } \\
\text { substantive aspects of the innovation, such as general characteristics, } \\
\text { effects, and requirements for use, in a selfless manner. }\end{array}$ & $\begin{array}{l}\text { I would like to know } \\
\text { more about it }\end{array}$ \\
\hline Unrelate & Unconcerned & Little concern about the innovation & $\begin{array}{l}\text { I am concerned about } \\
\text { some other things }\end{array}$ \\
\hline
\end{tabular}

the effective ICT integration in schools. This study aimed at explaining secondary school teachers' concerns about ICT integration in teaching and learning in Pakistan.

\section{THEORETICAL FRAMEWORK}

Teachers' concerns are significant in determining the adoption and implementation of educational innovations, (Puteh, Salam, \& Jusoff, 2011). Taking into account teachers' concerns about ICT integration Hall and Hord (1987) concerned based adoption model (CBAM) is used in this study. The model consists of stages of concern, change configuration and level of use of an innovation. The model has earned phenomenal acceptances and has been widely used. This is because CBAM provides a useful framework for analyzing concerns of those involved in change implementation (Gasaymeh, 2017; Hao \& Lee 2017; Pepe, 2016; Sultana, 2015). CBAM stages of concerns (SoC) categorizes teachers' concerns into seven stages (unconcerned-refocusing) (see Table 1). Concerns are beliefs and feelings towards an innovation and changes over time and in stages (Fuller, 1969). 
In the unconcerned stage (stage 0 ), teachers have little or no concern or involvement with the innovation. In the informational stage (stage 1), teachers lack knowledge about the innovation, and their role in its implementation. In this stage, they are interested in knowing about the general characteristics and other related information about an innovation. In the personal stage (stage 2) of concern teachers feel disquiet about the affects the innovation may have on them as a person. In the management stage (stage 3 ), the concerns emerge about the operation and process of implementation, including the management of information and resources. The consequence stage (stage 4), encompasses the impact of the innovation, it may have, on student and teachers' learning. In the collaboration stage (stage 5), concern converges on coordination and cooperation with various stakeholders. In the refocusing stage (stage 6), teachers consider how to modify the innovative practice and explore alternatives to the prevailing use of an innovation.

The intensity of each concern ranges from lower internal (stages $0-2$, early-stage concerns) to higher external (stages 3-6, later stages concerns). The nature of the stages may overlap and are not exclusive of each other. The concern stages are developmental, and categories are centered on self, task and impact. Teachers' concern, though, may not progress sequentially and later-stage concerns are critical in improving teachers' professional practice (Fuller 1969; Hall \& Hord 2006). Emergence of concern results from change or innovation (Hall \& Hord 2006), and change creates opportunity for learning.

The reason for using CBAM as a theoretical framework for this study is twofold. First, is its strength of guiding innovation users from the unconcerned towards refocusing concerns (Dawson, Swain, Johnson, \& Ring, 2004). Since this study aims at exploring teachers' concerns so, the model helps in identifying teachers' most relevant stage of concern with relation to ICT integration. Second, is to help teachers and schools towards strategizing ICT integration from the perspective of teachers' particular stages of concern. For, example peak informational stage of teachers informs about their need of gaining more information about ICT integration. Thus, teachers' capacity building needs equal consideration along with other measures such as provision of ICT resources.

\section{PREVIOUS STUDIES}

Fong, Al-Rawajfih, and Idros (2010) study in Amman on teachers concerns about e-learning finds them dominantly at the stage of 'personal' concern. Male and female teachers did not show any difference in any of these stages. From the perspective of teaching experiences, teachers with 1-5 years experience were at the stage of 'collaboration' while the rest were at the 'personal' stage. It was proposed that teachers' concerns related to management, informational and consequence contributed significantly towards their integration of e-Learning.

Puteh et al. (2011) used the CBAM model to evaluate teachers' concerns in implementing science literacy among preschool teachers. Their results indicated that majority of the teachers were at the personal, information and consequence stages. This, according to them, illustrated teachers' worries and feelings of uncertainties with relation to their roles in the process of adopting the innovation.

Similarly, a study in the context of Pakistan (Sultana, 2015) has used CBAM for launching the ICT based online teacher education program at one of the public universities in the country. The study finds the model very much appropriate towards exploring university faculty concerns about an innovation.

Pepe (2016) study, with using CBAM as a theoretical framework, examined teachers' concerns about their training for using the iPads. Study's results indicated that teachers were little concerned about extra training on classroom time and organization. They were found with conflicts between their interests and teaching responsibilities while integrating iPads. Results also inform that these teachers were highly concerned about developing working relationships with fellow faculty members to maximize the benefits of iPad training.

In their study Hao and Lee (2017) identified that, in Taiwan, the pre service teachers concerns were most intense in the self-concern stage and then fluctuated from task-concern to impact-concern. Findings of the study offer valuable insights for conceptualizing teacher education as to how levels of concern, self-efficacy for teaching, teacher knowledge and demographics influence the change process of Web 2.0 integration in instructions.

Gasaymeh (2017) studying Jordanian university faculty members' concern related to the use of learning management system (LMS) in their educational practices informs that most intense concerns of faculty members arose in the early stages of the introduction of the technology. The findings suggest that in order to institutionalize the use of LSM in the university, faculty members needed support to address their high intensity of concerns about the LMS use. In order to help faculty members, the study suggest, that there is a need to address their concerns in these early stages.

All these studies using CBAM as a theoretical framework suggest that teachers' concern remains fundamental towards and better informs abut ICT use in teaching and learning. Studies portrayed different peak scores amongst the teachers and across different contexts. Despite, there existed a pivotal contribution of CBAM as a theoretical framework and in particular with its diagnostic nature (George, Hall, \& Stiegelbauer, 2013) yet these studies could 
not grasp the reasons causing any peak stages of teachers' concern. For example, teachers' high personal concern (Gasaymeh, 2017), collaborative concern (Pepe, 2016), personal, informational and consequence concern (Puteh et al., 2011) doesn't portray the causes triggering higher teachers' stages of concern. This study, with the realizing this knowledge gap, in addition to identifying the intensity of teachers' concern, also investigated about the reasons that caused their particular concern regarding ICT integration. Similarly, studies in the past and in particular in Pakistan (e.g. Sultana, 2015) are conducted in the university context rather than focusing school level teachers' concerns with relation to ICT integration. This aspect also leaves a research gap in terms of investigating secondary school teachers' concern in Pakistan in this regard. Moreover, the use of an explanatory mixed method research method makes the study distinct from the past studies as those studies mostly employed either quantitative or qualitative research method. Employing a mixed method research this study produced more meaningful results in terms of identifying teachers' concerns and the reasons associated with their particular stages of concern.

\section{PURPOSE OF THE STUDY}

The current study aimed at investigating secondary school teachers' concern about ICT integration in schools in Pakistan. Moreover, the study took into account the aspect of generating knowledge and insights that may help schools, in Pakistan and elsewhere with similar contexts, integrate ICT in the process of teaching and learning. Providing insights towards accommodating teachers' peak stages of concern with relation to ICT integration remained one of the key purposes of the study. In addition, the study also investigated about the reasons associated with teachers' stages of concern regarding ICT integration. The following research questions were articulated to attain the purpose of the study.

1. What are Pakistani secondary school teachers' concern about ICT integration in teaching and learning?

2. What are the reasons that teachers perceive to be associated with causing their stages of concern about ICT integration?

\section{RESEARCH METHOD}

This study used an explanatory mixed method research (Newman, 2014) to address the research questions of the study. Research question one mainly aimed at identifying teachers' particular concern about ICT integration and quantitative research method could better accommodate the purpose. Research question two on the other hand looked at investigating about the reasons associate with teachers' concerns form teachers' perspective and hence qualitative method was employed in this regard. The overall purpose of the mixed method research was testing both objective perspective and providing in-depth understanding (Creswell, 2009; Johnson \& Christensen, 2004) of teachers' stages of concern and the underplaying reasons of their concerns about ICT integration. Explanatory research outlined the existing concern model and extended it (Newman, 2014) to know the intensity of Pakistani secondary school teachers' concerns about ICT integration.

\section{Participants}

Since the purpose of the study was to investigate teachers' concern about ICT integration it was important to select participants who have been familiar with ICT integration. With this purpose schools were identified where ICT resources have been provided and ICT related staff (ICT teacher or ICT assistant) is posted. More importantly, it was to make sure that ICT integration remains integral to those school plans. The set criterion was fulfilled by 40 public secondary schools with 300 teachers. All these 300 secondary school teachers (165 male \& 135 female) were recruited as research participants for the quantitative part of the study. 35 participants for the qualitative part of the study were purposefully selected (Creswell, 2009) on the basis of five teachers with the peak scores on each of the seven stages (stage-0 to stage-6) in order to generate deeper understanding of factors associated with teachers each of the seven stages of concern. In qualitative research, adequacy refers to the amount of data collected, rather than to number of subjects as in quantitative research. Adequacy was attained when sufficient data was collected and saturation occurred (Newman, 2014).

\section{Instrument}

This study used Hall and Hord (1987) stages of concern questionnaire (SoCQ), for its quantitative part, to explore teachers' concern about ICT integration in their teaching and learning. SoCQ is used to determine the intensity of individuals' concerns about an innovation (George, Hall, Stiegelbauer \& Litke, 2008). The validity, reliability, and internal consistency of SoCQ were thoroughly tested (George et al. 2008). The SoCQ had four parts: the cover page, the introductory page, a total of 35 items divided into seven scales to assess individuals' concerns. The participants marked each item on a 0-7 Likert scale, where " 0 " represented a completely irrelevant item for the respondent and " 7 " represented a completely relevant item for the respondent. 
Table 2. Questions related to stages of concern

\begin{tabular}{ccccccc}
\hline Stage 0 & Stage 1 & Stage 2 & Stage 3 & Stage 4 & Stage 5 & Stage 6 \\
\hline Q3 & Q6 & Q7 & Q4 & Q1 & Q5 & Q11 \\
\hline Q12 & Q14 & Q13 & Q8 & Q10 & Q18 & Q20 \\
\hline Q21 & Q15 & Q17 & Q16 & Q24 & Q27 & Q22 \\
\hline Q23 & Q26 & Q28 & Q25 & Q32 & Q29 \\
\hline Q30 & Q35 & Q33 & Q34 & & Q31 \\
\hline
\end{tabular}

Table 3. Cronbach's Alpha change facilitator style questionnaire $(\mathrm{N}=276)$

\begin{tabular}{cccccccc}
\hline Stages & $\mathbf{0}$ & $\mathbf{1}$ & $\mathbf{2}$ & $\mathbf{3}$ & $\mathbf{4}$ & $\mathbf{5}$ \\
\hline Cronbach's Alpha & .93 & .92 & .94 & .94 & .96 & .96 & 94 \\
\hline
\end{tabular}

In addition, semi structured interviews were used as an instrument for qualitative data collection. Certain guiding questions were developed and data was generated through administering these questions. In the process, other probing questions were also asked to clarify certain aspects that emerged during the interaction with the participants. These guiding questions included asking about the underlying causes of teachers' concerns.

\section{Reliability and Validity of the Instrument}

To measure the validity of the SoCQ, the developers compared the stages of concern scale to other variables of the CBAM model. To find the relationship they used "Inter-correlation matrices, judgments of concern based interview data, and confirmation of expected group differences and changes over time to investigate the validity of the SoCQ scores" (George et al., 2006, p. 12). In May 1974, the 195-item instrument was piloted among elementary school teachers and faculty. After this pilot study, the number of items in the questionnaire was reduced to 35 from 195 with five items in each stage of concern. During $1975-76$, the 35 item SoCQ was used in 11 cross sectional and longitudinal studies (George et al., 2006).

The SoCQ technical manual concludes that "[.... Concern] profiles like this one add support not only to the validity of the SoCQ, but also to the overall concern theory" (George et al., 2006, p. 20). Similarly, other studies, for example Liu, Ritzhaupt \& Cavanaugh (2012); and Sultana (2015) confirm the reliability and validity of the SoC. This study also checked and confirmed the reliability and validity of the instrument (see Table 3).

\section{PROCEDURES}

Prior to delivering copies of the SoC questionnaire, to all the 300 participants, the researchers discussed the dissemination and collection of the surveys with each head teacher. A separate contact person was designated, from each school, to oversee the distribution and collection process of the instrument. In addition, an official letter from the concerned department was also earned and sent to the head teachers to extent their support towards allowing teachers to participate in the study. Copies of SoC questionnaire were put in individual envelopes, along with an informed consent form, and the appropriate number of questionnaires for each school was delivered to the designated contact person. After completing the questionnaire, teachers returned the survey, along with a signed copy of the consent form, in a sealed envelope. Out of the total $276(95 \%)$ teachers returned the filled questionnaire. Afterwards the analysis of SoC data 35 of the participants were selected and interviewed in order to collect the qualitative data. Each of the interviews was of the duration of 30-40 minutes and was audio recorded. Participants' written consent was also gained for their participation in the interviews.

\section{Data Analysis}

In this study a sequential data analysis (Creswell, 209) was used. Initially SoCQ data were analyzed followed by the analysis of the qualitative data, collected through semi structured interviews. In the analysis of teachers' stages of concern about ICT integration descriptive statistics were used. In the process of identifying stages of concern the guidelines of the SoCQ manual were followed. The data analysis of SoCQ can be done with both individual and group data (George, Hall, \& Stiegelbauer, 2013). The researchers calculated the raw score of each of the seven stages (George, Hall, Stiegelbauer, \& Litke, (2008). These raw scores, for each of the seven stages, were used for further statistical analysis using IBM-SPSS 24.

The concept formation through categories based on themes, concepts or similar features is to make sense of qualitative data (Newman, 2014) and the same remained fundamental in the process of qualitative data analysis. The analysis of results from early data analysis guided subsequent data collection (Miles \& Huberman, 1994). 
Table 4. Teachers' stages of concern about ICT integration

\begin{tabular}{lcccccccc}
\hline & Unconcerned & Informational & Personal & Management & Consequence & Collaboration & Refocusing \\
\hline \multirow{2}{*}{$\mathrm{N}$} & 276 & 276 & 276 & 276 & 276 & 276 & 276 \\
\cline { 2 - 9 } & Valid & 0 & 0 & 0 & 0 & 0 & 0 & 0 \\
\hline Mean & 75.8478 & 59.9964 & 57.6594 & 36.7826 & 6.8333 & 12.0036 & 12.7935 \\
\hline Median & 87.0000 & 57.0000 & 55.0000 & 34.0000 & 4.0000 & 9.0000 & 9.0000 \\
\hline Mode & 55.00 & 43.00 & 41.00 & 34.00 & 3.00 & 5.00 & 9.00 \\
\hline Std. Deviation & 26.43494 & 18.11127 & 19.07935 & 16.09008 & 9.73323 & 14.11498 & 17.13765 \\
\hline
\end{tabular}

Consequent to the need of qualitative data analysis and guided by the research questions, the data analysis in this phase involved coding technique to establish categories related to each of the themes or stages of concern.

The coding technique involved open, axial and selective coding. In the open coding and as a first phase coding themes were located and initial codes were assigned to categories. These themes were stemmed in as they emerged from the theoretical framework of the study in terms of all the seven stages (Newman, 2014).

In the second phase of coding, when all the data was coded, axial coding was opted. Axial coding refers to focus on themes, as established during the open coding, rather than the data itself (Newman, 2014). The axial coding involved identifying the axis of the key concepts in analysis. In this stage the researchers looked for categories or concepts that cluster together. In this phase, for example, the researchers looked for other categories that could be put into each stage of concern.

As a final phase selective coding was used that aimed at looking selectively for categories that illustrate themes and making comparison (Newman, 2014). For example, in the selective coding the researcher looked into underlying factors to be associated with teachers each stages of concern. In addition, qualitative data was analyzed through organizing it in categories based on codes and themes with identical concepts or features (Newman, 2014) to lead generating causeus associated with teachers' concerns about ICT integration.

\section{RESULTS AND DISCUSSION}

Data analysis transpires that respondents rated their level of concern differently amongst the seven stages of concern (unconcerned, informational, personal, management, consequence, collaboration and refocusing) (Table 4). The unconcerned stage stood higher with the mean score of 75.84, while personal, with 59.99, remain second and informational with 57.66 the third highest stage of concern of the respondents. In addition, management shows the mean score of 36.78 , refocusing 12.79 , collaboration 12.00 and consequence 6.83 .

These findings indicate that majority of the teachers are at the unconcerned, informational or personal stages about the use of ICT in their instructions. Teachers' high mean scores on unconcerned stage, as per SoC interpretation (George, Hall, \& Stiegelbauer, 2006) depict no information about whether the respondent is a user or non user. The scores rather show their degree of interest in and engagement with ICT integration in comparison to their other tasks and activities. This informs that there may be other tasks or interventions that influence teacher's inclination towards high unconcerned scores.

High score in informational stage indicates that the respondent like to know more about the innovation. They are not concerned about "nitty-gritty" details but, rather, want fundamental information about what the innovation is, what it will do, and what its use will involve (George et al. 2006). George et.al inform about the higher concerns as substantive in nature. With this particular concern teachers focus only on the structure and function of the ICT integration in teaching and learning. So, the higher scores in this stage do not explain the level of knowledge that the participants posses but rather indicate if they want to know more about the innovation.

Higher scores on personal concern inform about teachers' uncertainty regarding the demands of ICT integration (Puteh et al., 2011) and their inadequacy to meet those demands. They are also not sure about their role with the innovation. The individuals seem to be analyzing their relationship to the reward structure of the organization, determining their part in decision making, and considering potential conflicts with existing structures or personal commitment (Hall \& Hord 1987). In addition higher personal concerns might also involve the financial status implications of the program for teachers.

Management concerns also depict reasonable higher mean score. Higher score at this stage refers to teachers' attention being focused on management and logistic aspects of ICT integration. They may be concerned about the availability of and accessibility to ICT resources within their schools. Issues related to efficiency, organization of resources and time demands are utmost important for the teachers with the higher management concern.

All these stages of concerns, including unconcerned, informational, personal and management, being high, reveals teachers more at the unrelated, personal and task patterns. These teachers are far from considering the use of ICT in teaching in learning from the perspective of its impacts on the overall teaching and learning practices. For 


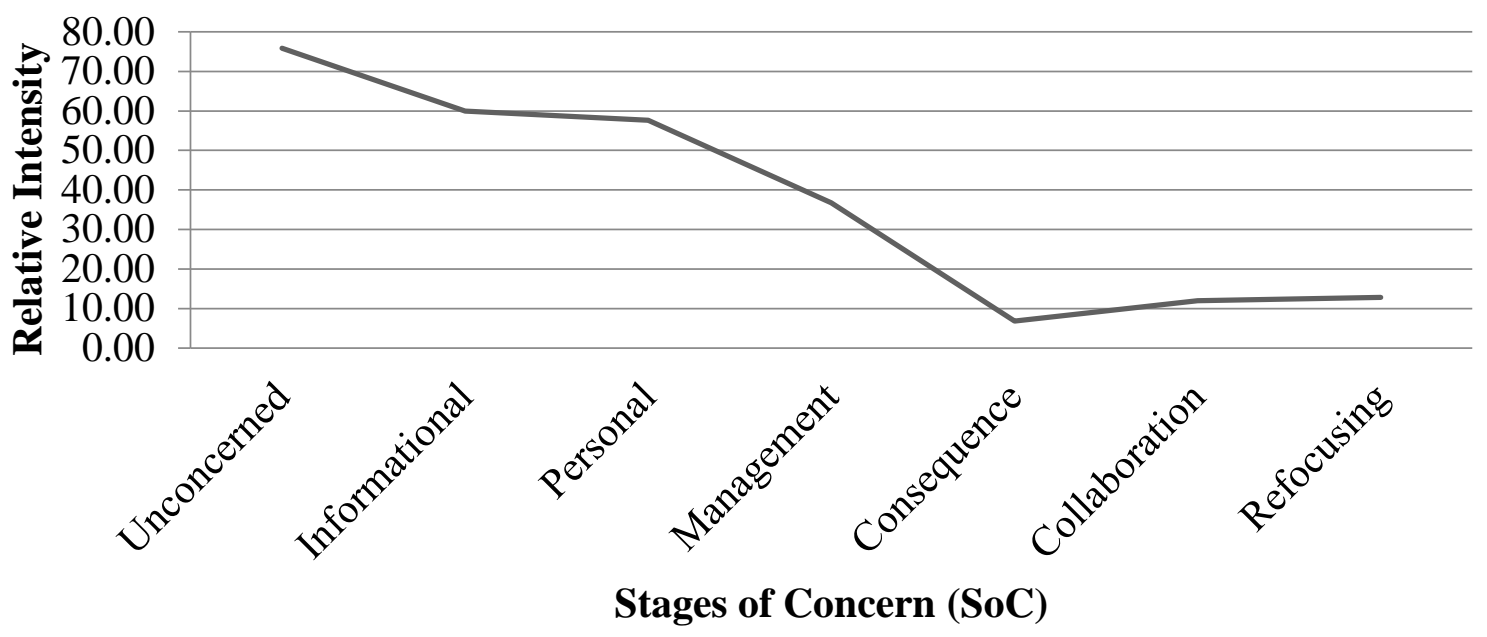

Figure 1. Concern profile of secondary school teachers about ICT integration

Table 5. Summary of qualitative data

\begin{tabular}{|c|c|c|c|c|}
\hline Pattern & Stages & Themes & Frequency & Percent \\
\hline \multirow{3}{*}{ Unrelated } & \multirow{3}{*}{ Unconcerned } & Preoccupied with tasks & 14 & $67 \%$ \\
\hline & & Lack of interest & 4 & $19 \%$ \\
\hline & & Other priorities (task accomplishment) & 3 & $14 \%$ \\
\hline \multirow{8}{*}{ Personal } & \multirow{2}{*}{ Informational } & Less information about ICT integration & 11 & $73 \%$ \\
\hline & & Seeking more information about ICT use & 4 & $27 \%$ \\
\hline & \multirow{6}{*}{ Personal } & Personal benefits (monitory benefits, promotion) & 4 & $24 \%$ \\
\hline & & Recognition & 4 & $24 \%$ \\
\hline & & More time and energy requirement for ICT integration & 3 & $18 \%$ \\
\hline & & Change in role & 2 & $12 \%$ \\
\hline & & Uncertainty & 2 & $12 \%$ \\
\hline & & Egocentric & 2 & $12 \%$ \\
\hline \multirow{4}{*}{ Task } & \multirow{4}{*}{ Management } & ICT resource management & 5 & $45 \%$ \\
\hline & & Time management & 3 & $27 \%$ \\
\hline & & Human resources management & 2 & $18 \%$ \\
\hline & & Non availability of ICT resources & 1 & $9 \%$ \\
\hline \multirow{8}{*}{ Impact } & \multirow{2}{*}{ Consequence } & Impacts on student learning & 8 & $89 \%$ \\
\hline & & Impacts on teachers' learning & 1 & $11 \%$ \\
\hline & \multirow{3}{*}{ Collaboration } & Learning from colleagues & 4 & $44 \%$ \\
\hline & & Learning from students & 3 & $33 \%$ \\
\hline & & Learning through social media groups & 2 & $22 \%$ \\
\hline & \multirow{3}{*}{ Refocusing } & Revising ICT use & 5 & $56 \%$ \\
\hline & & Experience based improvement of ICT use & 2 & $22 \%$ \\
\hline & & Looking for alternatives & 2 & $22 \%$ \\
\hline
\end{tabular}

an innovation to be best implemented needs teachers to be more concerned about consequence, collaboration and refocusing (Fong et al., 2010). This study finds teachers with low mean scores of 6.83, 12.00 and 12.79 on consequence, collaboration and refocusing stages of concern respectively. Their profile, (Figure 1), represents characteristics of a typical "nonuser profile" (Hall et al., 1986, p. 36).

The interview data aimed at identifying underlying causes of teachers high or peak concerns about ICT integration. The respondents pointed out certain issues that they considered to have caused their higher stages of concern (Table 5).

Respondents with high unconcerned stage were of the view that they were very much occupied with their tasks and hence could not think about any other innovations. A teacher shared that he could hardly manage his classes as he was preoccupied with taking six (out of eight classes a day). In addition, he had to teach more than one subject to different levels at the same time. He said: 
"Ohooo [a deep sigh expressing his hopelessness] how can you [researcher] ask about ICT use... I am not free even to have a cup of tea because of my busy schedule... I have to teach four subjects to four different class [grad 7 to 10] and have six periods [class and each class of 40 minutes duration] in a day.

Similarly another respondent added that he was not free to get engaged in ICT integration due to other tasks already in hand. He was of the view that:
"One should give priority to the tasks already in hand rather than looking for something new or additional... it will not be wise to do so but rather waste of time and energy... I find ICT integration as an addition task and is of less interest for me.

These respondents consider the innovation as of less or no interest for them and their responses portray the degree of low or no interest in and engagement with the use of ICT in teaching and learning (Hall \& Hord 2006).

The reasons for higher informational stage revealed ICT integration in teaching and learning to be very new to them. Those with higher scores on stage 1 required more awareness about the importance of ICT use in teaching and learning. A participant stated: "I am not sure that what it [ICT] in education mean... it is teaching computer to students... that I am not good at".

Such responses revealed minimal level of knowledge by the teachers. They still understood ICT integration as teaching computers. It is obvious that teachers will need more insights about ICT integration prior proceeding with its use (Hall \& Hord, 2011).

Respondent also shared that though they were not using ICT in the process of teaching and learning but they wanted to know more. A teacher said:

\section{"... I still want to know about ICT use in teaching and learning because I see them [ICT tools] being used in all walks of life so definitely would know about its use in education and in particular in my teaching practices"}

Respondents with high personal stage of concern thought of ICT integration from the perspective of its impacts on them. These impacts according to them were personal benefit, including monitory incentives, and career promotion. In addition, they considered level of commitment, time and energy the ICT integration required as negatively affecting them. A teacher stated: “We know there is no personal benefit in it [ICT integration]... no salary increase, no award or even recognition... then why would teachers take additional burden".

Similarly, another teacher shared: "Why should I follow any innovation if I feel comfortable with the way I teach...? I am the most senior teacher and nobody doubted my teaching strategies".

Teachers felt comfortable with their current teaching practices. Many of them also came up with a more ego centric perceptions such as being concerned with their status. They considered learning at this stage against their rank. "I still knew more than my junior colleagues...being a senior I cannot follow a junior, anyone who has been my student in the past".

This refers to SoC interpretation of people with higher score of personal stage being more egocentric and thinking of the benefit and loss with reference to ICT integration in teaching and learning.

Teachers with management concerns were anxious about managing their day to day tasks in terms of teaching different subjects to different grades (classes) at a time. In addition performing certain additional tasks, assigned by their head teachers, was also their prominent concern. The qualitative data also substantiate that teachers were concerned about managing their time and ICT resources. A teacher shared that:

"Dealing with day to day ICT related issues is really hard to manage, it takes too much of our time and energy and makes us disappoint to proceed with it... we have no support available in this regard, as a result we have quit the use of ICT in instructions".

Higher unconcerned, personal, informational and management concern indicate as substantive in nature where teachers focus only on the structure and function of the ICT integration in teaching and learning (George et.al. 2006). Participants with intense management concern informed about the time, and logistical aspects of the innovation being of worry for them. The majority of the respondents pointed out that the management of ICT resources was a difficult task for them. A teacher shared:

\footnotetext{
“... I was very much motivated and am still optimistic about ICT use but rather I am using them in my teaching and learning but most of the time I struggle with managing it... I feel more inclined towards how to manage those resources... they need proper care and understanding if they are not working at instances".
} 
In addition a teacher also identified certain issues like non availability of electricity and frequent breakdown of ICT tools as a bothering aspect and wanted more resources to be provided. Moreover, she also considered ICT integration a time consuming process. From lesson planning and managing resources to using those in the classroom, according to the respondent, consumed enough time. She shared that: "It [ICT tools] takes most of time to be managed and used.... Sometimes they don't work properly and waste enough time to amend".

Participants with peak scores on consequence stage indicated to be concerned about the use of ICT resources for the benefits of students. A teacher stated: "... we [teachers] need to think about the effectiveness of students in terms of its effectiveness for students rather than thinking of it either easy or difficult for us to use".

Another teacher further added that she was very much convinced that ICT use, in her instruction, was very much effective for students as it helped them get more involved in the process of learning. She pointed out that: “...I have observed a significant level of students' involvement in their learning since I have started using ICT in my teaching and learning".

The views of the respondents with collaboration concerns indicated their apprehension of working with others in relation to use of ICT tools in teaching and learning. A teacher was of the view that she must share her learning and experiences with colleagues to help them equally benefit from the use of ICT in their teaching and learning. She stated that:" I have good knowledge of ICT integration and have been frequently sharing the same with my colleague to help them use ICT in their instructions so they are also benefited from it".

These respondents considered each individual with having specific knowledge and skills. They emphasized upon sharing the same with colleague to make the best of it for the school as a whole. In particular the integration of ICT according to them, being still new for most of the teachers, needed more collective efforts.

Teachers with higher refocusing concern stated to have thought about improving the use of ICT integration to a next level. Despite, they still found it difficult to be achieved. They were of the view that the purpose could be achieved after getting frequently involved with the use of ICT. A teacher in this regard shared:

"When I used ICT first time in my class was just so nominal... I just engaged students telling about adding two to more digits...now I think of how to enable students to use it for their projects... they have and have shown great results".

The findings of the study are somehow consistent with previous studies that used concern based adoption model as a theoretical framework. For example, findings support studies in Taiwan (Hao \& Lee, 2017), in Jordan (Gasaymeh, 2017) and in Amman (Fong et al., 2010) who found the teachers with higher personal and informational concern and falling in the initial stage of implementing an innovation. The overall findings of the study, with the higher scores at informational or personal and task stages, also partially support the finding of Cetinkaya (2012) study of investigating mathematics teachers' concerns about implementing 6th-grade mathematics curriculum in Turkey. His findings inform that Turkish teachers' concerns were primarily at the personal and collaboration stages. These teachers were willing to implement the change but were confused with the curriculum innovation. They wanted to learn what other teachers knew and were doing to enrich their own knowledge and skills in implementation of the new curriculum. While in this study the teachers though exhibited that they needed to know more about ICT use in teaching and learning but did not consider or have not realized the collaborative aspect of professional development for ICT integration. Moreover, the findings are in contrast of a US study (Pepe, 2016) informing about teachers being less concerned about requiring additional training towards enhancing their ICT integration skills.

\section{IMPLICATIONS AND RECOMMENDATIONS}

Teachers' capacity enhancement stands higher at the reform agenda of ICT integration in the process of teaching and learning. This is to provide teachers the necessary information, knowledge and skills of ICT integration in order, as Gasaymeh (2017) rightly argue, to enable them move from initial stages of concern towards the impact level. Teachers' engagement in professional development activities can lead them enhance their efficacy of ICT integration that could really help them get out of the early stages of concern. It was quite evident that though similar resources were provided to all the sample schools but teachers with having more knowledge about ICT integration were more concerned about the impacts that ICT use may have on students learning.

Such development across the stages will need support at the school level that is continuous (Hao \& Lee, 2017) and in time so, teachers are able to deal with day to day issues related to ICT integration. A supportive school management (Jogezai et al., 2016) could be of significant importance towards making such continuous learning, being more collaborative in nature. To engage teachers learn from one another through developing good working relationships (Pepe, 2016) would be a viable way to achieve this very purpose. In addition, school management need to be mindful of the causes consequently raising teachers' initial concerns (unconcerned, informational and 
personal). As evident, through qualitative data analysis, teachers' workload and other additional tasks, assigned to them, had left them with the completion of those tasks as their ultimate priority. As a result ICT integration could not earh their interest. This is also an important aspect that school management, being close to their teachers, should look at.

Successful implementation will occur by chance if the concerns of teachers are not considered. It is pivotal for government, policy makers and school management to accurately assess the concerns of their teachers in order to make informed conclusions as to how the integration of ICT is proceeding or could be further improved. Schools should consider making ongoing, research-based decisions with the basis of continuous sampling as to the actual progress of implementation. They should be mindful that change is a process, not an event and that only introducing an innovation to a school will not cause its implementation. There is need of continuous assessment of teachers', as implementers, in terms of identification and rectification of affairs causing teachers non user profile of ICT integration. Concern based adoption model could be an effective evaluation tool in this regard.

Future research may look into factors that could make teachers' work place supportive towards ICT integration. Amongst the factors the role of school principals or head teaches, in this regard, could be a worth full object of study. In addition, studying head teachers' from the perspective of their own concern about ICT integration and their ICT related knowledge and skills may be of a high value towards effective ICT integration in schools in Pakistan and in other developing parts of the world.

\section{CONCLUSION}

The findings, or the diagnosis, of teachers' concerns about ICT integration clearly identified the extent teachers are concerned about ICT integration (Hall \& Steigelbauer, 2013). Though it was viable to know teachers' concerns about the implementation of ICT integration but the significant part of the study was to know the reasons associated with those concerns. The overall finding of teachers' stages of concern with relation to ICT integration informs about the innovation to be in its initial stage. Amongst the lack of sufficient knowledge of ICT use, most of the participants also remained uncertain about the impacts that the innovation may have on their role as teachers. Though these concerns, both informational and personal, reflected uneasiness regarding the use of ICT but they did not necessarily indicate resistance (George et. al. 2006). So, this may refer to their interest in the innovation and may provide a base for ICT integration in teaching and learning. The results portray that teachers who were having lower personal, informational and management concerns were more concerned about the impacts and outcomes of ICT integration in the process of teaching and learning. They preferred the intensive use of ICT in their instructions. Thus, this may, similarly make other teachers inclined towards ICT integration if their initial concerns are minimized.

The qualitative results additionally informed about the reasons that teachers considered highly associated with their higher stages of concern. For example, teachers' work load in terms of taking many classes in a day and engagement in other activities assigned by the management was highly associated with their higher unrelated concerns. Similarly, having less information about ICT integration the participants had intense informational concerns. They also were keen to know about personal benefits associated with the use of ICT. Management of time and resources was ultimately considered as key factor associated with their higher management concern. Consequently, teachers being more concerned about the impacts of ICT integration for students and their own learning caused their consequence, collaboration and refocusing concerns.

\section{REFERENCES}

Adil, A., Masood, A.M., \& Ahmed, M. (2013). Age and gender's association with information \& communication technology (ICT) usage into educational institutions of Pakistan. Sociology Mnd, 3(4), 325-332. https://doi.org/10.4236/sm.2013.34044

Almekhlafi, A. G., \& Almeqdadi, F. A. (2010). Teachers' perceptions of technology integration in the United Arab Emirates school classrooms. Educational Technology \& Society, 13(1), 165-175.

Alrwaished,N., Alkandari,A., \& Alhashem,F. (2017). Exploring in- and pre-service science and mathematics teachers' technology, pedagogy, and content knowledge (TPACK): What next? EURASIA Journal of Mathematics Science and Technology Education, 13 (9), 6113-6131. https://doi.org/10.12973/eurasia.2017.01053a

Altınay-Gazi, Z., \& Altınay-Aksal, F. (2017). Technology as mediation tool for improving teaching profession in higher education practices. Eurasia Journal of Mathematics, Science E Technology Education, 13(3), 803-813. https:/ / doi.org/10.12973/eurasia.2017.00644a

Baser-Gulsoy, V. G. (2011). Elementary teachers' perceptions towards ICT integration in teaching and learning process (Phd thesis). METU, Ankara. 
Creswell, J. (2009). Research design: Qualitative, quantitative, and mixed methods approach (3rd ed.). London, England: Sage Publications.

Dawson, K., Swain, C., Johnson, N., \& Ring, G. (2004). Partnership strategies for systemic integration of technology in teacher education. Contemporary Issues in Technology \& Teacher Education, 3(4), 482-495.

Fong, S. F., AL-Rawajfih, K., \& Idros, S. N. S. (2010). Stages of concern in integrating E-Learning in the Jordanian Discovery school. Asian Social Science, 6(8), 54-63. https:// doi.org/10.5539/ass.v6n8p54

Fullan, M. (2007). The new meaning of educational change. New York: Teachers College Press.

Fuller, F. (1969). Concerns of teachers: A developmental conceptualization. American Educational Research Journal, 6(2), 1207-1226. https:/ / doi.org/10.3102/00028312006002207

Gakuo, C. K., \& Kidombo, H. J. (2011). Closing the chasm: Are the secondary school teachers in Kenya using ICT effectively to deliver curriculum content? Retrieved on Jan, 2, 2018 from https:/ / profiles.uonbi.ac.ke/hkidombo/files/closing_the_chasm_e_learning_conference.pdf

Gasaymeh, A.M. (2017). Faculty members' concerns about adopting a learning management system (LMS): A developing country perspective. EURASIA Journal of Mathematics, Science and Technology Education, 13 (11), 7527-7537. https:/ / doi.org/10.12973/ ejmste/80014

George, A. A., Hall, G. E., Stiegelbauer, S. M., \& Litke, B. (2008). Measuring implementation in schools: Stages of concern questionnaire Austin, TX: Southwest Educational Development Laboratory. Retrieved on Aug, 5, 2016 from http://www.sedl.org/cbam/socq_manual_201410.pdf

Hall, G. E., \& Hord, S. M. (2006). Implementing change: Patterns, principles and potholes (2nd ed). Boston: Allyn and Bacon.

Hall, G., \& Hord, S. (1987). Change in schools: Facilitating the process. Albany, NY: State University of New York.

Hao, Y., \& Lee, K.S. (2017): Inquiry of pre-service teachers' concern about integrating Web 2.0 into instruction, European Journal of Teacher Education, 1-19. https:/ / doi.org/10.1080/02619768.2017.1285278

Harris, J. B., \& Hofer, M. J. (2011).Technological pedagogical content knowledge (TPACK) in action. Journal of Research on Technology in Education, 43(3), 211-229. https:/ / doi.org/10.1080/15391523.2011.10782570

Hassan, T., \& Sajid, A. R. (2013). ICTs in learning: problems faced by Pakistan. Journal of Research and Reflections in Education, 7(1), 52-64.

Jogezai, N. A., Ismail, S. A. M. M., \& Ahmed, F. (2016). ICT integration \& the role of school leadership: perceptions of head teachers of secondary schools in Quetta Pakistan. International Journal of Innovation and Scientific 27(1), 155-163.

Johnson, R. B., \& Christensen, L. (2004). Educational research: Quantitative, qualitative, and mixed approaches (2nd ed.). Boston, MA: Pearson Education. https:// doi.org/10.3102/0013189X033007014

Kanwal, A., Jan, F., \& Azhar, Z. (2014). An empirical evolution framework of ict in education sector of Pakistan. International Journal of Innovation and Scientific Research, 11(2), 585-597.

Kisirkoi, F.D. (2015). Integration of ICT in education in a secondary school in Kenya: A case study. Literacy Information and Computer Education Journal (LICEJ), 6(2), 904-909. https:// doi.org/10.20533/licej.2040.2589.2015.0253

Majoka, M. I., Fazal, S., \& Khan, M. S. (2013). Implementation of information and communication technologies (ICTs) in education course: A case from teacher education institutions in Pakistan. Bulletin of Education and research, 35(2), 37-53.

Mikre, F. (2011). The roles of information communication technologies in education review article with emphasis to the computer and internet. Ethiop. J. Educ. \& Sc., 6(2), 1-16.

Ministry of education Government of Pakistan. (2009). National Education Policy Pakistan. Retrieved on Jan 2, 2018 from http:/ / unesco.org.pk/education/teachereducation/files/National\%20Education\%20Policy.pdf

Ministry of Education Government of Pakistan. (2004). National information and communication technology strategy for education in Pakistan. Retrieved on Dec 23, 2017 from http://www.ilearnpakistan.org/pdf/NationalInformation-Communications-Strategy-Pakistan.pdf

Ministry of Planning, Development \& Reform Pakistan Vision. (2015). Pakistan vision 2025. Retrieved on Dec 12, 2017 from http://www.ntb.gov.pk/gop/index.php?q=aHR0cDovLzE5Mi4xNjguNzAuMTM2L250Yi91c2 VyZmlsZXMxL2ZpbGUvUGFraXN0YW4tVmlzaW9uLTIwMjUucGRm

Miranda, H. P., \& Russell, M. (2012). Understanding factors associated with teacher-directed student use of technology in elementary classrooms: A structural equation modelling approach. British Journal of Educational Technology, 43, 652-666. https:/ / doi.org/10.1111/j.1467-8535.2011.01228.x 
Mwalongo, A. (2011). Teachers' perceptions about ICT for teaching, professional development, administration and personal use. International Journal of Education and Development using Information and Communication Technology, 7(3), 36-49.

Newman, W. L. (2014). Qualitative and quantitative approaches. London, UK: Pearson Education Limited.

Niekerk, M. V., \& Blignaut, S. (2014). A framework for information and communication technology integration in schools through teacher professional development. Africa Education Review, 11(2), 236-253. https:// doi.org/10.1080/18146627.2014.927159

Nisar, M. W., Munir, E., \& Shad, S. A. (2011). Usage and impact of ict in education sector; a study of Pakistan. Australian Journal of Basic and Applied Sciences, 5(12), 578-583.

Ouyang, W. (2017). Application strategy of modern network technology in higher vocational teaching activities. EURASIA Journal of Mathematics Science and Technology Education, 13(10), 7009-7014. https://doi.org/10.12973/ejmste/78715

Pepe, T. M. (2016). Teacher perceptions and attitudes of classroom technology integration related to iPad (Phd thesis). Walden University. USA.

Puteh, S. N., Salam, K. A. A., \& Jusoff, K. (2011). Using CBAM to evaluate teachers' concerns in science literacy for human capital development at the preschool. Learning Innovation and Intervention for Diverse Learners, 14, 8187.

Qadir, M. J., \& Hameed, A. (2014). A study of the usefulness of Punjab it labs project in schools of Punjab, Pakistan as perceived by students. World Journal on Educational Technology, 6(1).

Ramorola, M. Z. (2013). Challenge of effective technology integration into teaching and learning. Africa Education Review, 10(4), 654-670. https:/ / doi.org/10.1080/18146627.2013.853559

Razzak, N. A. (2013). Challenges facing school leadership in promoting ICT integration in instruction in the public schools of Bahrain. Educ Inf Technol, 20, 303-318. https:/ / doi.org/10.1007/ s10639-013-9283-7

Rosenberg, J. M., \& Koehler, M. J. (2015). Context and technological pedagogical content knowledge (TPACK): A systematic review. Journal of Research on Technology in Education, 47(3), 186-210. https://doi.org/10.1080/15391523.2015.1052663

Shaikh, Z. A., \& Khoja, S. A.(2011). Role of ICT in shaping the future of Pakistani higher education system. The Turkish Online Journal of Educational Technology, 10(1), 1303-6521.

Sultana, N. (2015). Application of Concerned based adoption model (CBAM) for launching the information technology based teacher education programme at AIOU. Asian Journal of Social Sciences E Humanities, 4(3), 153-166.

Swan, K., \& Hofer, M. (2011). In Search of technological pedagogical content knowledge. Journal of Research on Technology in Education, 44(1), 75-98. https:/ / doi.org/10.1080/15391523.2011.10782580

$\mathrm{Xu}, \mathrm{A} .$, \& Chen,G. (2016). A study on the effects of teachers' information literacy on information technology integrated instruction and teaching effectiveness. Eurasia Journal of Mathematics, Science $\mathcal{E}$ Technology Education, 12(2), 335-346. https:/ / doi.org/10.12973/eurasia.2016.1222a

Yucel, C., Acun, I., Tarma, B., \& Mete, T. (2010). A model to explore Turkish teachers' ICT integration stages. The Turkish Online Journal of Educational Technology, 9(4), 1-9.

Zhou,G., Xu,J., \& Martinovic,D. (2017). Developing pre-service teachers' capacity in teaching science with technology through microteaching lesson study approach. EURASIA Journal of Mathematics Science and Technology Education, 13(1), 85-103. https:/ / doi.org/10.12973/eurasia.2017.00605a

\section{http://www.ejmste.com}

